South African government threatens university subsidies

\section{Cape Town}

South AfricA's universities are anxious $y$ waiting to see whether the government seriously intends to carry out its threat to cut the subsidies on which they all depend. The first sign of impending trouble came on 5 August, when the Minister of National Education, F.W. de Klerk, summoned all university principals to tell them of the government's dissatisfaction with political activity on campuses.

Since then, the relevant ministers of education (for the various racial groups) have sent letters to the chairmen of university councils demanding that universities themselves act to prevent disruption of academic activities. They are also required to prevent staff and students from using university facilities to promote civil disobedience of any kind, support any boycott or work stay-away, organize any illegal gathering or promote the image of any illegal or 'affected' organization.

This last provision is clearly aimed at restricting the National Union of South African Students (NUSAS), which was declared an 'affected' organization in the mid-1970s, thereby preventing it from receiving funds from overseas. The student representative councils of the Universities of the Witwatersrand, Cape Town, Rhodes and Natal are affiliated to the union, which would be unable to function if it were denied its campus base.

The government is demanding that the universities discipline any student or staff member who engages in prohibited activities or conducts him or herself in a seditious manner within $2 \mathrm{~km}$ of the perimeter of the campus. Furthermore, it requires that the universities inform the relevant minister of education of any incident of unrest and any occurrence of such activities, and of the disciplinary steps taken. If the universities fail to meet the minister's requirements, he threatens to enforce a subsidy cut. All South Africa's universities receive a subsidy from the state, which amounts to at least 75 per cent of the revenue of each university.

The minister's threats are clearly directed primarily at the Universities of Cape Town (UCT) and the Witwatersrand, both of which have a substantial minority (about 20 per cent) of black students. Two incidents took place on the UCT campus last month. In the first, a group of students at one of the residences disrupted a speech by the former South African ambassador in London, Dr Dennis Worrall. (Subsequently, one student was suspended until the end of the year and several others fined by the university court.) The following day, Mr Tom Linda, ex-mayor of Ibhayi, a Port Elizabeth township, was chased off the campus by students after having arrived to address a meeting of the so-called Moderate Students Movement The meeting was held in defiance of a ban imposed on it by the UCT principal and vice-chancellor, Dr Stuart Saunders, on the grounds that the procedures laid down by the university for inviting controversial speakers to campus were not followed.

University councils had until the end of August to respond to the government's proposals. Although these responses have not been made public, it is widely understood that the five open universities have rejected the proposals as being completely unworkable. There has apparently also been significant opposition to the proposals from academics at Stellenbosch, the country's leading Afrikaans-medium university. There is some speculation in academic circles that de Klerk may back down on his threat to cut subsidies. The possibility also exists that the minister is threatening to exercise powers that are ultra vires, and could be tested in court.

While the government is claiming to be interfering in university autonomy in the interests of avoiding unrest, it seems to be employing people with the aim of fuelling precisely such incidents. Saunders met Minister of Law and Order Adriaan Vlok last week to discuss the recent disclosure by a second-year social science student, Daniel Pretorius, that he was a paid security-police spy operating at UCT. This was admitted by Vlok. Affidavits have subsequently been collected by the university alleging that he has acted as an agent provocateur campus more than once, including an incident at a demonstration earlier this year in which he encouraged other students to throw stones at a police vehicle.

\title{
East and West Germany claim to open border for scientists
}

\section{Bonn}

EXPORT restrictions notwithstanding, East and West Germany signed an agreement in Bonn on 10 September for scientific exchange in all fields.

Until now, scientists from West Germany have rarely been allowed to visit their East German colleagues, let alone to collaborate with them. The new agreement also permits East German scientists to travel out of the Soviet bloc.

The new agreement, signed after an exhausting 14 years of negotiations, calls for a joint commission to oversee cooperation. The West German Research and Technology Ministry (BMFT) announced that 27 projects have already been agreed. The commission will sit starting on 1 November to settle the details of these projects and to decide on other areas for cooperation. The 27 projects include research on AIDS, nuclear and nonnuclear energy, and biotechnology.

Both sides face major obstacles in implementing the agreement, signed last week during the historic first visit to West Germany of the East German leader, Erich Honecker. West German industry has run into trouble before with Western restrictions regulating what may be exported to countries in the Soviet bloc.

It is hard to imagine that collaboration in a field such as computer-integrated manufacturing, included in the initial list of 27 , could possibly go smoothly. But the BMFT played down the possibility that its Western partners might balk at the agreement. BMFT official Karl Christoph Blaesing pointed out how few of the first 27 projects involve high technology. East
Germany, the largest computer exporter in the Soviet bloc, may have a few secrets of its own. But East German Science and Technology Minister Herbert Weiz said there are "no limitations" on what can be discussed with West German scientists. "No one gives orders to our sovereign state" about what it can buy or sell, he said.

Some are sceptical of just how open East Germany will be. Nobel physics laureate Klaus von Klitzing, says "I will try to invite a particular scientist and see if he, not his boss or somebody else, really comes."

Steven Dickman

Vera Rich adds - The East German view of last week's agreement is that it is but part of a continuing process of detente. East German sources point out that many proposed areas of cooperation such as energy, environment and health, had been scheduled for discussion at the 1980 Hamburg Science Forum.

East Germany is now more conscious of environmental issues, and has been cooperating with West Germany in several projects, even agreeing that West German organizations with headquarters in West Berlin should be allowed to take part despite their constitutional non-existence in East German eyes.

The high-technology parts of the agreement are likely to be the most interesting to East Germany, which is opposed to western restrictions of collaboration in these fields but was nevertheless quick to insist last week that it has the intellectual capacity to render them nugatory. But the prize for East Germany would be reduced dependence on Comecon, the Warsaw Pact's economic organization. 